Bangladesh J. Bot. 49(2): 367-374, 2020 (June)

\title{
CYTOLOGICAL CHANGES INDUCED BY CLETHODIM IN PISUM SATIVUM PLANT
}

\author{
Sazada Siddiqui* and Sulaiman Alrumman \\ Department of Biology, College of Science, King Khalid University, Abha 61413, Saudi Arabia
}

Keywords: Herbicide, Seed germination, Radicle length, Mitotic index, Pisum sativum

\begin{abstract}
Effects of clethodim treatment on mitotic cells of $P$. sativum were studied in the present investigation. Pisum sativum seeds are treated with different concentrations of clethodim varying from $0.01,0.02,0.03$ and $0.04 \%$ for 1 and $2 \mathrm{hrs}$ and their effect on seed germination, radicle length, mitotic index and chromosomal anomalies were investigated. The outcomes reveal that treatment of clethodim on $P$. sativum seeds diminishes seed germination, radicle length, and mitotic index in dose-dependent manner. Also, in clethodim treated seeds which are time and concentration dependent, an escalation in the proportion of abnormal mitotic phases was observed. C-mitosis, fragments, precocious separation, stickiness and bridges were the most frequently observed deviations. The results revealed that frequently used herbicide clethodim has a substantial cytotoxic effect on P. sativum.
\end{abstract}

\section{Introduction}

To enhance the yield of crops, pesticides that include insecticides, fungicides and herbicides are used widely. Each year, greater than 0.0025 billion tons of pesticides are used in agrarian crops globally (Van der Werf 1996). Previously reported results have shown the genotoxic effect of various frequently applied pesticides (Garrett et al. 1986, Siddiqui et al. 2009) primarily through their application on vital biomolecules for example DNA (Crosby 1982). Due to their highly stable nature, various pesticides do not undergo rapid biological and physio-chemical degradation, so they are a grave threat to both plants and animals.

Herbicide clethodim falls into the cyclohexanedione oxime class. From post-emergence, clethodim is active as an herbicide against various species of grass weed mostly in sunflower, soybean, cotton, and other broad-leaved plants (Edwards 2005). Maleic hydrazide (MH) is one of the few herbicides which prevents the synthesis of proteins and nucleic acids (Siddiqui et al. 2008). Mutagenic action of glyphosate, alachor and maleic hydrazide was reported by (Siddiqui $e t$ al. 2012), diclofop-methyl and lindane has been stated by (Anila and Ditika 2013) and Anilofos was described by Arzu et al. (2015) on root tip cells of plant. P. sativum is used in the manufacturing of ayurvedic medicines, fertilizer and vegetable (Davies et al. 1985). It is the most frequently used legume, which is an important source of dietary protein. Although P. sativum is a prospective versatile crop, very few studies are available on the effect of clethodim on $P$. sativum plant especially in Asir region (Abha) of Kingdom of Saudi Arabia. In the present analysis an effort was made to examine the toxic effect of clethodim on P. sativum.

\section{Materials and Methods}

Herbicide clethodim falls into the cyclohexanedione oxime class. It is procured from the Delta chemical company of Saudi Arabia in Riyadh. P. sativum seeds, variety ARKIL were obtained from the Indian Council of Agricultural Research - Bhoj Krishi Vigyan Kendra, Near Village Naktara, P. O. Bankhedi, NH-86 Ext., Raisen Sagar Road, Bhopal.

\footnotetext{
*Author for correspondence: <sasdeky@kku.edu.sa>.
} 
Uniform sized and wholesome seeds of $P$. sativum were taken and soaked in double distilled water for six hrs at a $\mathrm{pH}$ of 6.7. P. sativum seeds were soaked for one and two hrs in different concentrations $(0.01,0.02,0.03$ and $0.04 \%)$ of $150 \mathrm{~mL}$ clethodim solutions in $250 \mathrm{ml}$ glass beaker. For supplying adequate air to the seeds, they were shaken repeatedly. The seeds were then suitably washed with double distilled water in order to remove any residual quantity of clethodim, if present. In control group, the seeds were treated with double distilled water. After 1 and $2 \mathrm{hrs,}$ on sterilized filter paper 30 seeds from various concentrations kept in Petri dishes of $15 \mathrm{~cm}$ in diameter and incubated in a plant growth cabinet in dark for 72 hrs having a temperature of $20 \pm$ $2^{0} \mathrm{C}$. Germination of seeds was defined by perceiving the radicle development. By means of a millimeter ruler, at every $24 \mathrm{hrs}$ up to $72 \mathrm{hrs}$, radicle length was assessed of the seeds germinated (Siddiqui 2016, Siddiqui et al. 2018). The whole experiment was done thrice under same requirements.

As stated by Qian (1998), root tips of different treatment groups were treated for mitotic preparation. Root tips were incised and fixed for $24 \mathrm{hrs}$ in Carnoy's fixative solution and then shifted in $70 \%$ alcohol and kept in a fridge for further use. At room temperature, root tips were hydrolyzed for 20 minutes in $5 \mathrm{~N} \mathrm{HCl}$ and stained for 1 hour in $2 \%$ acetocarmine. As stated by Savaskan and Toker (1991), chromosome spreads were prepared by means of squash method and slight amendments were made by Siddiqui et al. 2007. Entire slides were examined blind and the groups were coded. Using light microscope under oil immersion, in metaphase and anaphase plates, mitotic index and chromosomal anomalies were examined. At least 500 cells were scored from each slide and mitotic index was calculated. In at least 50 metaphase or anaphase plates in each slide, chromosomal anomalies such as, c-mitosis, fragments, precocious separations, sticky chromosomes, and bridges formation were calculated.

The data of seed germination, root length, mitotic index and mitotic phases were analyzed statistically using one-way ANOVA test using GPIS software (1.13) (Graphpad, California, USA). Turkey test was performed in order to evaluate the significant differences between each treatment group and untreated group. The level of statistical significance was in all cases $p \leq 0.05$. Three independent experiments were carried out and all values are stated as mean $\pm \mathrm{SE}$.

\section{Results and Discussion}

In control group, after 1 hour clethodim treatment $(0.88 \pm 0.37)$ of seeds germinated at $24 \mathrm{hrs}$, which increased to $(1.00 \pm 0.00)$ at 48 and $72 \mathrm{hrs}$ and at $2 \mathrm{hrs}(0.66 \pm 0.03)$ of seed germinated at $24 \mathrm{hrs}$ which increased to $(1.0 \pm 0.00)$ at 48 and $72 \mathrm{hrs}$ (Table 1$)$.

At $24 \mathrm{hrs}$, after 1 hour clethodim treatment at $0.01 \%$ concentration, approximately $(0.27 \pm$ $0.02)$ seed germination was reported and $(0.13 \pm 0.01)$ seed germination was recorded for 0.02 to $0.04 \%$ concentration, which were significantly $(\mathrm{p} \leq 0.001)$ lower than control. After 1 hour treatment with clethodim at $0.01 \%$ concentration, at $48 \mathrm{hrs}$ approximately $(0.66 \pm 0.04)$ seed germination was recorded and $(0.47 \pm 0.02),(0.53 \pm 0.03)$ and $(0.40 \pm 0.02)$ seed germination were listed for $0.02,0.03,0.04 \%$ concentration respectively, which were significantly $(\mathrm{p} \leq 0.001)$ lesser then control. A similar pattern was recorded for $72 \mathrm{hrs}$. At $24 \mathrm{hrs}$, after $2 \mathrm{hrs}$ clethodim treatment at 0.01 and $0.02 \%$ concentration, $(13 \pm 0.01)$ seed germination was reported and no seed germination was recorded in 0.03 to $0.04 \%$ concentration, which were significantly ( $\mathrm{p} \leq 0.001$ ) lesser than control. A similar pattern was recorded for 48 and $72 \mathrm{hrs}$.

Effect of treatment of clethodim for 1 and $2 \mathrm{hrs}$ on radicle length of $P$. sativum is shown Table 2 . The radicle length increased with surge in time in both 1 and $2 \mathrm{hrs}$ treatment with clethodim. In control, after one-hour clethodim treatment, at $24 \mathrm{hrs}$ the radicle length was $2.03 \pm 0.65 \mathrm{~cm}$ which increased to $3.25 \pm 1.03 \mathrm{~cm}$ at $48 \mathrm{hrs}$ and $3.96 \pm 0.97 \mathrm{~cm}$ at $72 \mathrm{hrs}$. Reduction in radicle length was 
observed in dose-dependent manner with rise in concentrations. There was a significant $(\mathrm{p} \leq$ 0.001 ) reduction in radicle length when compared with control. In control group, after two hrs clethodim treatment, the radicle length increased with enhancement in time which was $1.54 \pm 0.11$ $\mathrm{cm}$ at $24 \mathrm{hrs}, 1.9 \pm 0.4 \mathrm{~cm}$ at $48 \mathrm{hrs}$ and $2.5 \pm 1.0 \mathrm{~cm}$ at $72 \mathrm{hrs}$ which was significantly $(\mathrm{p} \leq 0.001)$ lesser than control. In treated seeds at lower doses (0.01 to $0.02 \%)$, clethodim have significant ( $\mathrm{p} \leq$ 0.001 ) effect on radicle length when compared with control and at

Table 1. Seed germination of Pisum sativum seeds treated with various concentration of clethodim for 1 and 2 hrs.

\begin{tabular}{|c|c|c|c|c|}
\hline \multirow{2}{*}{$\begin{array}{l}\text { Concentration } \\
(\%)\end{array}$} & \multirow{2}{*}{$\begin{array}{l}\text { Treatment } \\
\text { Time }\end{array}$} & \multicolumn{3}{|c|}{ Seed germination $(\%)$} \\
\hline & & $24 \mathrm{hrs}$ & $48 \mathrm{hrs}$ & $72 \mathrm{hrs}$ \\
\hline $\mathrm{CN}$ & $1 \mathrm{hr}$ & $0.88 \pm 0.37$ & $1.00 \pm 0.00$ & $1.00 \pm 0.00$ \\
\hline $0.01 \%$ & & $0.27 \pm 0.02^{¥}$ & $0.66 \pm 0.04^{¥}$ & $0.93 \pm 0.25$ \\
\hline $0.02 \%$ & & $0.13 \pm 0.01^{¥ \mu}$ & $0.47 \pm 0.02^{¥}$ & $0.87 \pm 0.36$ \\
\hline $0.03 \%$ & & $0.13 \pm 0.01^{¥ \mu}$ & $0.53 \pm 0.03^{¥ a}$ & $0.80 \pm 0.40^{\mu}$ \\
\hline $0.04 \%$ & & $0.13 \pm 0.01^{¥ \mu}$ & $0.40 \pm 0.02^{\ddagger}$ & $0.53 \pm 0.03^{¥}$ \\
\hline $\mathrm{CN}$ & $2 \mathrm{hrs}$ & $0.66 \pm 0.03$ & $1.0 \pm 0.00$ & $1.00 \pm 0.00$ \\
\hline $0.01 \%$ & & $0.13 \pm 0.01^{¥}$ & $0.53 \pm 0.02^{¥}$ & $0.88 \pm 0.34$ \\
\hline $0.02 \%$ & & $0.13 \pm 0.01^{¥}$ & $0.53 \pm 0.02^{¥}$ & $0.73 \pm 0.44^{£}$ \\
\hline $0.03 \%$ & & $0.00 \pm 0.00^{¥}$ & $0.13 \pm 0.01^{¥}$ & $0.66 \pm 0.27^{¥ \mu}$ \\
\hline $0.04 \%$ & & $0.00 \pm 0.00^{¥}$ & $0.13 \pm 0.01^{¥}$ & $0.33 \pm 0.02^{¥ £}$ \\
\hline
\end{tabular}

${ }_{\mathrm{p}}^{\mu} \leq 0.05 ;{ }^{\mathfrak{k}} \mathrm{p} \leq 0.01 ;{ }^{¥} \mathrm{p} \leq 0.001$ compared to control. Data are mean of three replicates $\pm \mathrm{SEM}$. $\mathrm{CN}=$ Untreated group.

Table 2. Radicle length of Pisum sativum seeds treated with various concentration of clethodim for 1 and 2 hrs.

\begin{tabular}{|c|c|c|c|c|}
\hline \multirow{2}{*}{$\begin{array}{l}\text { Concentration } \\
(\%)\end{array}$} & \multirow{2}{*}{$\begin{array}{l}\text { Treatment } \\
\text { Time }\end{array}$} & \multicolumn{3}{|c|}{ Radicle length (CM) } \\
\hline & & $24 \mathrm{hrs}$ & $48 \mathrm{hrs}$ & $72 \mathrm{hrs}$ \\
\hline $\mathrm{CN}$ & $1 \mathrm{hr}$ & $2.03 \pm 0.65$ & $3.25 \pm 1.03$ & $3.96 \pm 0.97$ \\
\hline $0.01 \%$ & & $0.50 \pm 0.29^{¥}$ & $2.44 \pm 1.37^{\mathfrak{f}}$ & $2.91 \pm 1.70^{¥}$ \\
\hline $0.02 \%$ & & $0.50 \pm 0.38^{¥}$ & $1.92 \pm 0.78^{¥}$ & $2.50 \pm 1.20^{¥}$ \\
\hline $0.03 \%$ & & $0.27 \pm 0.07^{¥}$ & $1.52 \pm 0.61^{¥}$ & $1.90 \pm 0.70^{¥ £}$ \\
\hline $0.04 \%$ & & $0.23 \pm 0.061^{¥ \mu}$ & $1.07 \pm 0.23^{¥ £}$ & $1.50 \pm 0.32^{¥ £}$ \\
\hline $\mathrm{CN}$ & $2 \mathrm{hrs}$ & $1.54 \pm 0.11$ & $1.90 \pm 0.40$ & $2.5 \pm 1.00$ \\
\hline $0.01 \%$ & & $0.58 \pm 0.07^{¥}$ & $1.00 \pm 0.02^{¥}$ & $1.3 \pm 0.05^{¥}$ \\
\hline $0.02 \%$ & & $0.36 \pm 0.02^{¥ £}$ & $0.63 \pm 0.03^{¥}$ & $1.3 \pm 0.02^{¥}$ \\
\hline $0.03 \%$ & & $0.00 \pm 0.00^{¥}$ & $0.44 \pm 0.02^{¥ \mu}$ & $0.9 \pm 0.03^{¥ £}$ \\
\hline $0.04 \%$ & & $0.00 \pm 0.00^{¥ £}$ & $0.32 \pm 0.01^{¥}$ & $0.5 \pm 0.02^{¥ £}$ \\
\hline
\end{tabular}

${ }^{\mu} \mathrm{p} \leq 0.05 ; £ \mathrm{p} \leq 0.01 ; ¥ \mathrm{p} \leq 0.001$ compared to control. Data are mean of three replicates $\pm \mathrm{SEM}$. $\mathrm{CN}=$ Untreated group

higher concentration ( 0.03 to $0.04 \%$ ), no radicle length was observed at 24 hrs after 2 hrs clethodim treatment. However, at 48 and 72 hrs, reduction in radicle length was reported in dosedependent manner from lower to higher concentrations. It resulted in a significant $(\mathrm{p} \leq 0.001)$ 
reduction in radicle length as compared to control. Higher inhibitory effect of clethodim treatment is reported in $2 \mathrm{hrs}$ as compared to one hour.

Mitotic index indicates the rate of cell division or proliferation. Effect of 1 and $2 \mathrm{hrs}$ treatment of clethodim on the mitotic index of $P$. sativum are summarized in Fig. 1. The untreated seeds showed a mitotic index $14.54 \pm 2.0$ for $1 \mathrm{hr}$ and $18.0 \pm 2.15$ for $2 \mathrm{hrs}$, respectively. For 1 and $2 \mathrm{hrs}$ clethodim treated seeds, the mitotic index was found to decrease with rise in concentrations. Even at the lowest dose $(0.01 \%)$, cElethodim caused a significant reduction in mitotic index as compared to untreated group $(\mathrm{p} \leq 0.001)$. With further surge in concentrations, there was a steady decline in mitotic index, which was significantly lesser than control $(\mathrm{p} \leq 0.001)$ at all concentrations. At $0.04 \%$ concentration, the mitotic index was nearly 3.5 times less than untreated group $4.25 \pm 0.8$ at $1 \mathrm{hr}$ and $5.5 \pm 0.91$ at $2 \mathrm{hrs}$, respectively. Two hrs clethodim treatment has higher inhibitory effect on mitotic index as compared to one-hour treatment.

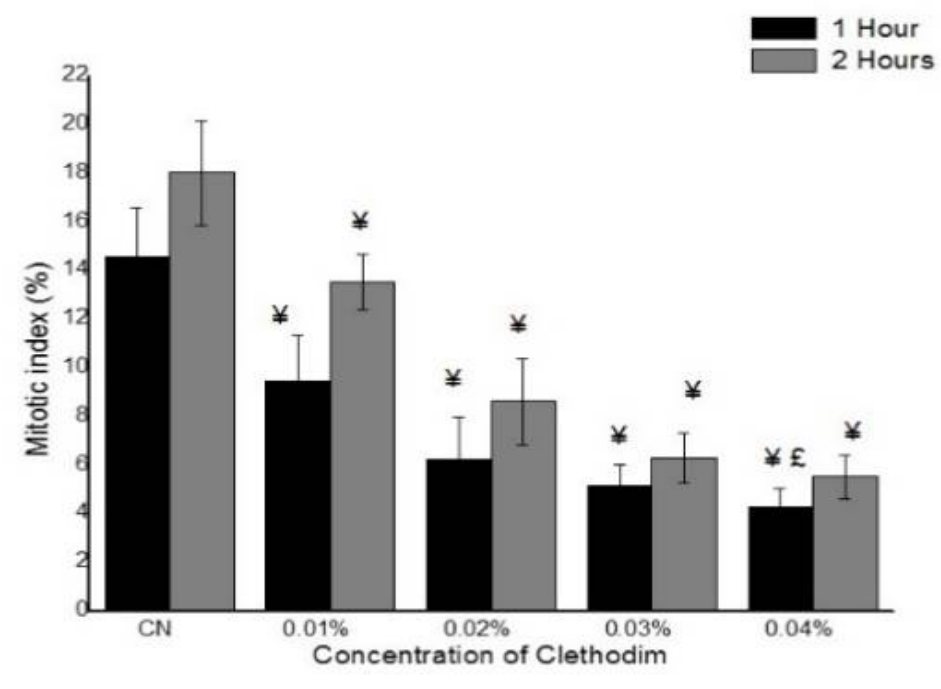

Fig. 1. Mitotic index in metaphase-anaphase plate of $P$. sativum root tips exposed to different concentrations of clethodim for $1 \mathrm{hr}$ and $2 \mathrm{hrs}$.

For different time durations of 1 and $2 \mathrm{hrs}$, the mitotic anomalies in root tips of $P$. sativum subjected to various clethodim doses are illustrated in Table 3 and Fig. 2. The chromosomal arrangement from root tips of clethodim treated seeds revealed numerous mitotic anomalies for example c-mitosis (C-M), fragments (Fr), precocious separations (PS), sticky chromosomes (STC) and bridges (Br) in 1 and $2 \mathrm{hrs}$. In untreated group, in metaphase-anaphase plate no chromosomal abnormalities were detected. Augmented occurrences of chromosomal irregularities such as cmitosis, fragments, precocious separation, sticky chromosome, and bridges were stated in 1 and 2 hrs clethodim treated seeds of $P$. sativum, which were significantly higher $(\mathrm{P} \leq 0.001)$ as compared to control. But increased frequencies of chromosomal anomalies such as c- mitosis, fragments, precocious separation, sticky chromosome, and bridges were found to be higher in 2 hrs as compared to one-hour clethodim treated seeds. Among these aberrations sticky chromosomes was the most detected chromosomal aberration (4.5\%). Additionally, the incidence of remaining irregularities were sticky chromosomes > c-mitosis > bridges > fragments > precocious separations in one-hour clethodim treated seeds of $P$ sativum. Even at lower concentrations of clethodim $(0.01$ and $0.02 \%)$ all the above stated anomalies were found in the mitotic preparations, 
PS, SC and C- mitosis being the most frequent. Analogous trend was found in clethodim seeds treated at higher concentrations $(0.03$ and $0.04 \%)$. A significantly higher $(\mathrm{p} \leq 0.001)$ incidence of all these abnormalities were obviously evident. Analogous trend was found in chromosomal abnormality of $2 \mathrm{hrs}$ clethodim treated seeds. Moreover, the occurrence of remaining irregularities were sticky chromosomes > c-mitosis > precocious separations > fragments > bridges in $2 \mathrm{hrs}$ clethodim treated seeds. Among these anomalies sticky chromosomes was (4.2\%), c-mitosis (3.2\%), precocious separations (2.32\%) fragments (2.0\%) and bridges (1.7\%) in $2 \mathrm{hrs.}$

Table 3. Cytogenetic analysis in metaphase-anaphase plate of $\boldsymbol{P}$. sativum root tips exposed to different concentrations of clethodim for 1 and 2 hrs.

\begin{tabular}{|c|c|c|c|c|c|c|}
\hline \multirow{2}{*}{$\begin{array}{l}\text { Concentration } \\
(\%)\end{array}$} & \multirow{2}{*}{$\begin{array}{l}\text { Treatment } \\
\text { time }\end{array}$} & \multicolumn{5}{|c|}{ Metaphase - Anaphase anomalies } \\
\hline & & C-mitosis & Fragments & P. Sep. & Sticky Chr. & Bridges \\
\hline $\mathrm{CN}$ & $1 \mathrm{hr}$ & $0.00 \pm 0.0$ & $0.0 \pm 0.0$ & $0.0 \pm 0.00$ & $0.0 \pm 0.0$ & $0.0 \pm 0.00$ \\
\hline $0.01 \%$ & & $0.80 \pm 0.2^{\mu}$ & $1.8 \pm 0.3^{¥}$ & $1.5 \pm 0.35^{¥}$ & $2.5 \pm 0.8^{¥}$ & $1.5 \pm 0.30^{¥}$ \\
\hline $0.02 \%$ & & $1.91 \pm 0.9^{¥ £}$ & $1.6 \pm 0.2^{¥}$ & $1.9 \pm 0.20^{¥ £}$ & $1.9 \pm 0.9^{¥}$ & $1.7 \pm 0.75^{¥}$ \\
\hline $0.03 \%$ & & $3.00 \pm 1.0^{¥ £}$ & $1.7 \pm 0.2^{¥}$ & $1.6 \pm 0.30^{\ddagger}$ & $2.5 \pm 1.0^{¥}$ & $2.0 \pm 0.20^{¥}$ \\
\hline $0.04 \%$ & & $2.9 \pm 0.9^{¥ \mathfrak{x}}$ & $2.0 \pm 0.4^{\mu ¥}$ & $1.9 \pm 0.90^{¥}$ & $4.5 \pm 1^{¥}$ & $3.2 \pm 0.21^{¥}$ \\
\hline $\mathrm{CN}$ & $2 \mathrm{hrs}$ & $0.0 \pm 0.0$ & $0.0 \pm 0.00$ & $0.0 \pm 0.00$ & $0.0 \pm 0.0$ & $0.0 \pm 0.00$ \\
\hline $0.01 \%$ & & $1.0 \pm 0.2^{£}$ & $2.0 \pm 0.30^{¥}$ & $1.2 \pm 0.20^{¥}$ & $2.1 \pm 0.4^{¥}$ & $1.3 \pm 0.30^{¥}$ \\
\hline $0.02 \%$ & & $2.1 \pm 0.9^{¥ £}$ & $1.4 \pm 0.70^{¥}$ & $1.8 \pm 0.20^{¥}$ & $2.2 \pm 0.4^{¥}$ & $1.0 \pm 0.34^{\ddagger}$ \\
\hline $0.03 \%$ & & $3.3 \pm 1.1^{¥}$ & $1.4 \pm 0.20^{¥}$ & $1.3 \pm 0.70^{¥}$ & $3.3 \pm 1.0 ¥$ & $1.4 \pm 0.45^{¥ £}$ \\
\hline $0.04 \%$ & & $3.2 \pm 1.2^{¥ £}$ & $2.0 \pm 0.45^{\mu ¥}$ & $2.3 \pm 0.32^{¥}$ & $4.2 \pm 0.21$ & $1.7 \pm 0.21^{¥}$ \\
\hline
\end{tabular}

${ }^{\mu} \mathrm{p} \leq 0.05 ;{ }^{£} \mathrm{p} \leq 0.01 ;{ }^{¥} \mathrm{p} \leq 0.001$ compared to control. Data are mean of three replicates $\pm \mathrm{SEM}$. $\mathrm{CN}=$ Untreated group

Throughout growth and sprouting progressions in seeds, the metabolic reactions regarding synthesis, molecular dilapidation are inspiring to regulate, as metabolism and cell integrity are related with a variability of enzymes roles that are specific to all species (Vieira et al. 2006). Seed germination is affected by light, humidity level, incubation temperature and oxygen concentration (Seregin and Kozhevnikova 2006). After clethodim treatment, seeds planted instantly exhibited a postponement and inhibition in the seed germination on $P$. sativum. The study divulges the fact that delay in germination of $P$. sativum seeds are associated with the doses of clethodim treatment. There might be a possibility that the effect of clethodim is similar to the effect of glyphosate on indole-3-acetic acid which is an endogenous auxin that diminishes the percentage of germination and development in plants (Clay and Griffin 2000, Siddiqui et al. 2012).

Delay and inhibition in the radicle length of $P$. sativum is caused by clethodim treatment. This delay was mostly correlated to cell elongation throughout activity of apical meristematic cells, differentiation and the delay and inhibition in protein synthesis (Webster and MacLeod 1996, Seth et al. 2007).

To evaluate the incidence of cellular division, the mitotic index is a consistent parameter (Fernandes et al. 2007). The cytotoxic potential of clethodim in P. sativum is illustrated by concentration and time dependent inhibition of mitotic index. In the present investigation, due to decline in mitotic index, clethodim showed a cytotoxic effect. Analogous actions on mitotic index were described by former study in A. cepa (Andrioli et al. 2012). Due to the mitodepressive effect of compound, there might be a substantial decrease in MI as clethodim hinders the normal cell 
cycle consequently leading to a reduction in number of dividing cells (Arzu et al. 2015). The decrease in mitotic index may also be attributed to blocking of G1phase or subduing or prevention of DNA synthesis or effect of substance at $\mathrm{G}_{2}$ phase of cell cycle (Anila and Ditika 2013). Hence, reduction in mitotic index in the present investigation could be due to the above-mentioned causes. C-mitosis, fragments, precocious separation, sticky chromosome, and bridges are the most found chromosomal abnormalities. They are caused either due to spindle failure (c-mitosis) or dysfunction of chromatin (stickiness, bridges, and fragments). Chromosome bridges are formed due to fusion and breaking of chromosome or chromatid (Luo et al. 2004). Stickiness is generally of irreversible nature and it possibly results in cell death (Liman et al. 2010). C-mitosis are formed by disruptions in the formation of spindle fibers (Haliem 1990) or unstable microtubules (Odeigah et al. 1997). Chromosome fragments are also formed by breakdown of double stranded DNA caused by reactive oxygen. Fragments results from chromosomes stickiness and their inability of parting of chromatids to poles (Fusconi et al. 2007, Siddiqui 2018). Precocious separation results from the restraining effect of herbicides on spindle proteins and their capability to make exchange of sister chromatids (Gichner et al. 2002). It is reported in many studies that in cells, genomic variability is caused by free radicals.
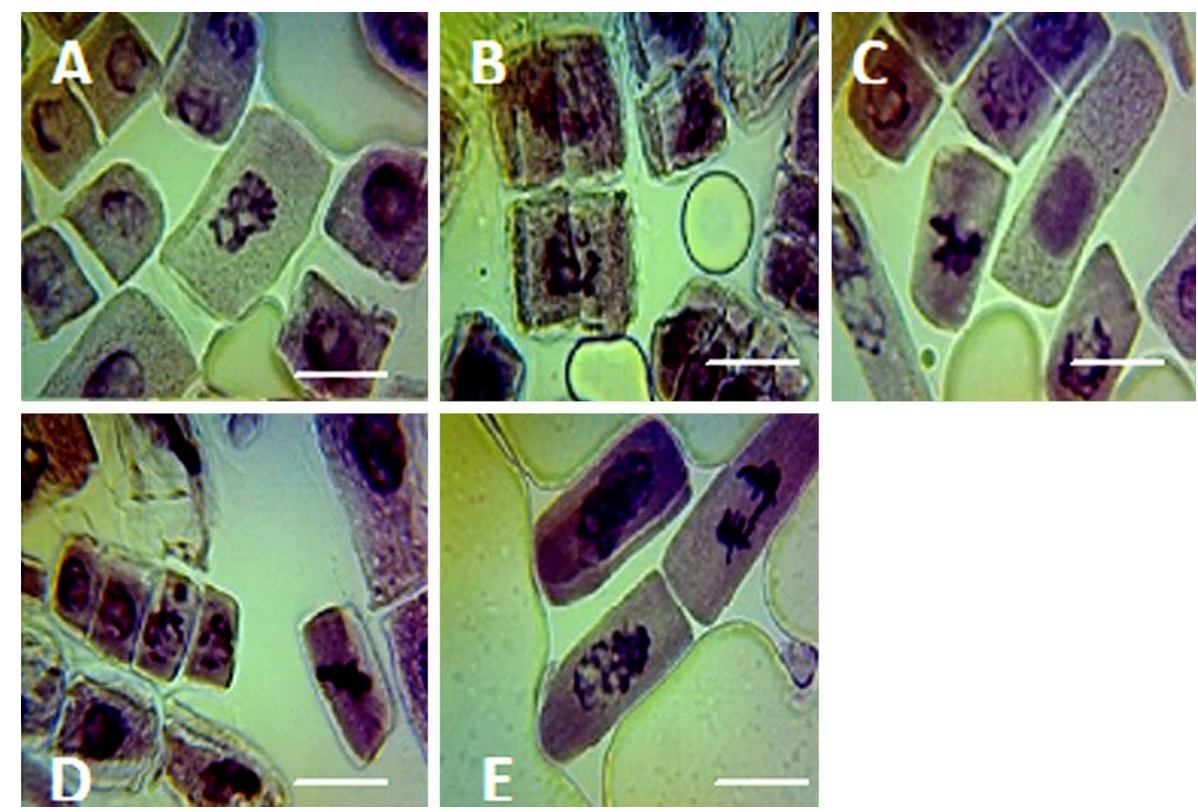

Fig. 2. The effect of clethodim on chromosomal aberrations of $P$. sativum. $\mathrm{A}=\mathrm{C}$-mitosis, $\mathrm{B}=\mathrm{Fragments,}$ $\mathrm{C}=$ Precocious Separation, $\mathrm{D}=$ Stickiness, $\mathrm{E}=$ Bridges, Scale bars $=10 \mu \mathrm{m}$.

Present study shows that clethodim herbicide which is generally used in Saudi Arabia for agricultural crops can cause cytotoxic effects and can pose a serious threat to plants, animals, and environment. The present investigation is of great importance as it is useful in deciding the proper dosages of herbicide clethodim which can be used for agricultural purposes so that it maintains its beneficial functions but have inconsequential cytotoxic effects on plants. It is important to extend the research work on the goods developed from seeds/plants subjected to these herbicides regarding their vulnerability to acclimate strain and fight diseases and nutritive value. 


\section{Acknowledgments}

Authors are grateful to Deanship of Scientific Research at King Khalid University, Abha, Kingdom of Saudi Arabia for providing technical and administrative support. The authors (Sazada Siddiqui and Sulaiman Alrumman extend their appreciation to the Deanship of Scientific Research at King Khalid University, Abha, Saudi Arabia for funding this work through research groups program under grant number R.G.P.1/49/39.

\section{References}

Andrioli NB, Soloneski S, Larramendy ML and Mudry MD 2012. Cytogenetic and microtubule array effects of the zineb containing commercial fungicide formulation Azzurro ${ }^{\mathrm{RX}}$ on meristematic root cells of Allium cepa L. Mut. Res. 742: 48-53.

Anila MD and Ditika K 2013. Cytotoxic and genotoxic potency screening of two pesticides on Allium cepa L. Proc. Tech. 8: 9-26.

Arzu O, Dilek A, Yasin E and Sevim FE 2015. Potential cytotoxic effect of anilofos by using Allium cepa assay. Cytotechnology 67: 783-791.

Clay PA and Griffin JL 2000. Weed seed production and seedling emergence responses to late-season glyphosate applications. Weed Sci. 48: 481-486.

Crosby DG 1982. Pesticides as environmental mutagens. In: Fleck, R. A., Hollander, A. (eds.). Genetic toxicology: an agricultural perspective. Plenum Press, New York. pp. 201-218.

Davies DR, Berry GJ, Heath MC and Dawkins TCK 1985. Pea (Pisum sativum L). In: Summerfield, R.J., Roberts, E.H. (eds.). Grain legume crops. Williams Collins, London. pp. 147-198.

Edwards D 2005. Reregistration Eligibility Decision (RED) for Sethoxydim. United States Environmental Protection Agency. pp.1-27.

Fernandes TCC, Mazzeo DEC and Marin-Morales MA 2007. Mechanism of micronuclei formation in polyploidizated cells of Allium cepa exposed to trifluralin herbicide. Pestic. Biochem. Physiol. 88: 252259.

Fusconi A, Gallo C and Camusso W 2007. Effects of cadmium on root apical meristems of Pisum sativum L: cell viability, cell proliferation and microtubule pattern as suitable markers for assessment of stress pollution. Mutat. Res. 632: 9-19.

Garrett NE, Stack HF and Waters MD 1986. Evaluation of the genetic activity profiles of 65 pesticides. Mut. Res. 168: 301-325.

Gichner T, Menke M, Stavreva DA and Schubert I 2002. Maleic hydrazide induces genotoxic effects but no DNA damages detectable by the comet assay in tobacco and field bean. Mutagenesis 15: 385-389.

Haliem AS 1990. Cytological effects of the herbicide sencor on mitosis of Allium cepa. Egypt J. Bot. 33: 93104.

Liman RD, Akyl YE and Konuk M 2010. Testing of the mutagenicity and genotoxicity of metolcarb by using both Ames/Salmonella and Allium test. Chemosphere 80: 1056-1061.

Luo LZ, Werner KM, Gollin SM and Saunders WS 2004. Cigarette smoke induces anaphase bridges and genomic imbalances in normal cells. Mutat. Res. 554: 375-385.

Odeigah PGC, Nurudeen O and Amund OO 1997. Genotoxicity of oil field wastewater in Nigeria. Hereditas 126: $161-167$.

Qian XW 1998. Improvement on experiment method of micronucleus in root tip cell of Vicia faba. J Wenzhou. Norm. Coll. 19: 64-65.

Savaskan C and Toker MC 1991. The effects of various doses of gamma irradiation on the seed germination and root tips chromosomes of rye (Secales cereals L.). Turk. J. Bot. 15: 349-359.

Seregin V and Kozhevnikova AD 2006. Physiological role of nickel and its toxic effect on higher plants. Russ. J. Plant. Physiol. 53: 257-277. 
Seth CS, Chaturvedi PK and Misra V 2007. Toxic effect of arsenate and cadmium alone and in combination on Giant Duckweed (Spirodela polyrrhiza L.) in response to its accumulation. Environ.Toxicol. 22: 539549.

Siddiqui S, Meghvansi MK and Hassan Z 2007. Cytogen;etic changes induced by sodium azide (NaN3) on Trigonella foenum-graecum L seeds. S. Afri. J. Bot. 73: 632-635.

Siddiqui S, Khan SS, Meghvansi MK and Nazoora SA 2008. Mutagenic effect of herbicide maleic hydrazide on seed germination and radicle length on Trigonella foenum-graecum. Indian J. Appl. Pure. Biol. 23: 103-106.

Siddiqui S, Meghvansi MK, Wani MA and Jabee F 2009. Evaluating cadmium toxicity to the root meristem of Pisum sativum L. Acta. Physiol. Plant. 31: 531-536.

Siddiqui S, Meghvansi MK and Khan SS 2012. Glyphosate, alachor and maleic hydrazide have genotoxic effect on Trigonella foenum-graecum L. Bull. Environ. Contam. Toxicol. 88: 659-665.

Siddiqui S 2016. Inhibitory effects of leaf extracts on morphology of Pisum sativum cv. Arikil. Bangladesh J. Bot. 45: 243-246.

Siddiqui S 2018. Cytotoxicity induced by aluminum sulfate in cells of root meristem of Pisum sativum cv. Arikil. Bangladesh J. Bot. 47: 219-226.

Siddiqui S, Alamri S, Al-Rumman S and Moustafa M 2018. Allelopathic and cytotoxic effects of medicinal plants on vegetable crop pea (Pisum sativum). Cytologia 83: 277-282.

Van der Werf HMG 1996. Assessing the impact of pesticides on the environment. Agric. Ecosyst. Environ. 60: $81-96$.

Vieira MG, Von Pinho EV and Salgado KC 2006. Molecular techniques in seeds. Agric. Rep. 27: 88-96.

Webster PL and MacLeod RD 1996. The root apical meristem and its margin. In: Waishel Y., Eshel A, Kafkafi U (Eds) Plant Roots. The hidden half, 2nd edn., Marcel Dekker, New York. pp. 51-76. 